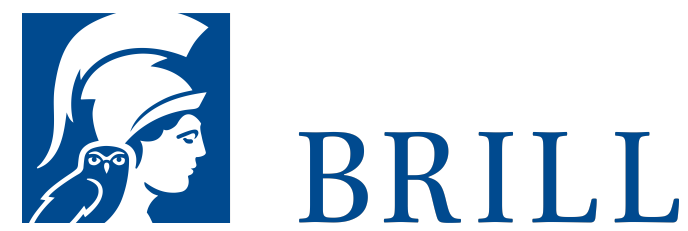

\title{
After Eden
}

Church Fathers and Rabbis on Genesis 3:16-21

Author: Hanneke Reuling

This volume charts the interpretation of Genesis 3:16-21 in a number of patristic and classical rabbinic sources. It is a case study in the reception of a biblical fragment in two intrinsically related yet distinct interpretative communities: early Christianity and rabbinic Judaism. Following the lead of the biblical text, this study sheds new light on each traditions' view of the human condition, more specifically on the way Church Fathers and Rabbis approach the themes of procreation, labour, mortality and corporeality.

The book carefully studies the reading of the biblical text as proposed by a number of representative and influential authors or documents, including Ambrose of Milan, Didymus the Blind, John Chrysostom and Augustine, as well as Genesis Rabbah and Avot de Rabbi Nathan. The introductions at the beginning of each chapter enable also the non-specialist to enter the distinct literary worlds of midrash and patristic Bible interpretation.

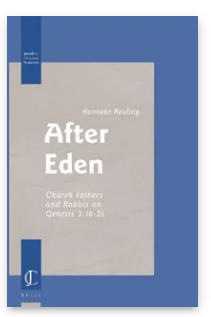

Pages: $x x, 380$

pp.

Language:

English

Subjects:

Biblical

Interpretations,

Biblical Studies

Publisher: Brill

Series:

Jewish and

Christian

Perspectives

Series, Volume:

10

E-Book (PDF)

Released online:

o1 Oct 2005

ISBN: 978-90-

47-41701-9

List price

USD \$173.00

Hardback

Publication date:

11 Oct 2005

ISBN: 978-90-

o4-14638-9

List price

USD \$173.00 
Hanneke Reuling recently obtained her Ph.D. from the Catholic Theological University of Utrecht (2004). She is appointed as office manager and curriculum coordinator at the Netherlands School for Advanced Studies in Theology and Religion.

For more information see brill.com

\begin{abstract}
Order information: Order online at brill.com +44330 3330049 | customerservices@brill.com Submission information: brill.com/authors
\end{abstract}

Titles published by Brill | Fink, Brill | mentis or Brill | Schöningh: +49(o)71 5413279216 | brill@brocom.de 